\title{
IMPACT OF HIGH-INTENSITY FOOTBALL ON THE COMPREHENSIVE QUALITY OF PHYSICAL FUNCTIONS
}

\author{
IMPACTO DO FUTEBOL AMERICANO DE ALTA INTENSIDADE NA QUALIDADE INTEGRAL \\ DEFUNÇÕES FISICAS \\ IMPACTO DEL FÚTBOL AMERICANO DE ALTA INTENSIDAD EN LA CALIDAD INTEGRAL DELAS \\ FUNCIONES FÍSICAS
}

\author{
Shihao Huang ${ }^{1}$ (D) \\ (Physical Education Professional) \\ Yahui Su² (D) \\ (Physical Education Professional) \\ Shiting $\mathrm{Wu}^{3}$ (D) \\ (Physician)

\section{Department of Sports and Leisure Studies, Hoseo University, Asan, Chungcheongnam-do, Republic of Korea. \\ 2. Hunan Vocational College for Nationalities, Yueyang, China. 3. The First Hospital of Hunan University of Chinese Medicine, Changsha, China.}

Correspondence:

Shihao Huang. Asan, Chungcheongnam-do, 31499, Republic of Korea. hsh200880677@163.com

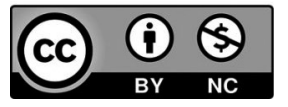

Original Article ARTIGO ORIGINAL Artículo Original

\begin{abstract}
Introduction: Football is a high-intensity, high-speed, high-strength physical exercise. It can effectively improve the overall qualities of endurance, strength, and speed. Objective: To determine whether football training impacts the physical function and quality of students. Methods: We use the physiological and biochemical indicators of football players to monitor their physical functions. Results: Football training can significantly improve the physical fitness of college students in terms of cardiopulmonary function, endurance, explosive power, flexibility, body balance, and coordination sensitivity. Conclusion: Football training can significantly reduce the basic heart rate of college students. It also significantly improves the flexibility and coordination sensitivity of these students. Level of evidence Il; Therapeutic studies - investigation of treatment results.
\end{abstract}

Keywords: Football; Physical fitness testing; Sports.

\section{RESUMO}

Introdução: O futebol americano é uma atividade física de alta intensidade, velocidade e força. Ele pode efetivamente aprimorar as qualidades de resistência, força e velocidade. Objetivo: Determinar se o treino de futebol americano tem impacto sobre a função e a qualidade físicas dos estudantes. Métodos: Os indicadores fisiológicos e bioquímicos dos jogadores foram utilizados para monitorar suas funções físicas. Resultados: O treino em futebol americano pode melhorar significativamente a aptidão física dos estudantes universitários no que diz respeito a sua função cardiopulmonar, resistência, poder de explosão, flexibilidade, equilibrio, e sensibilidade motora. Conclusão: O treino de futebol americano écapaz de reduzir significativamente a frequência cardíaca em repouso dos estudantes. Também trouxe melhoras significativas em sua flexibilidade e sensibilidade motora. Nível de evidência ll; Estudos terapêuticos - investigação de resultados de tratamento.

Descritores: Futebol Americano; Teste de Esforço; Esportes.

\section{RESUMEN}

Introducción: El fútbol americano es una actividad fisica de alta intensidad, velocidad y fuerza. Este puede efectivamente mejorar las calidades de resistencia, fuerza y velocidad. Objetivo: Determinar siel entrenamiento de fútbol americano tiene impacto sobre la función y la calidad físicas de los estudiantes. Métodos: Los indicadores fisiológicos y bioquímicos de los jugadores fueron utilizados para monitorear sus funciones físicas. Resultados: El entrenamiento en fútbol americano puede mejorar significativamente la aptitud física de los estudiantes universitarios en lo que respecta a su función cardiopulmonar, resistencia, poder de explosión, flexibilidad, equilibrio y sensibilidad motora. Conclusión: El entrenamiento de fútbol americano es capaz de reducir significativamente la frecuencia cardíaca en reposo de los estudiantes. También les aportó mejoras significativas en su flexibilidad y sensibilidad motora. Nivel de evidencia ll; Estudios terapéuticos - investigación de resultados de tratamiento.

Descriptores: Fútbol americano; Prueba de esfuerzo; Deportes.

\section{INTRODUCTION}

This topic is to study whether the implementation of football training impacts students' physical function and quality. The research can understand the effect of football training on college students' physical function and quality and actively explore new models of rapid development of football training. ${ }^{1}$ The research results of this article provide a theoretical basis for the development of football training on the physical function and quality of college students. Articles can help promote college students to participate in sports activities and improve their awareness of physical fitness.

\section{METHOD}

\section{Research object}

We take boys in the 14th and 15th grades of football in the Sports Institute, the indicators that affect physical function and quality, and the football-assisted training methods as the research objects. 


\section{Research methods}

Literature data method

This article has consulted and integrated relevant physical function and football training data through China Howie. These materials provide a theoretical basis for the writing of this article.

\section{Experimental measurement method}

In this experiment, the experimental group consisted of 10 boys in the 14th-grade football special class of the Institute of Physical Education. The control group consisted of 10 boys in the 15th grade without football training. In this experiment, the experimental group was given football training for eight weeks. Train 4 times a week for 90 minutes each time. ${ }^{2}$ The control group received regular training. The football training content mainly includes ball technique, quality, and technical and tactical practice during the experiment.

\section{Mathematical Statistics}

We enter the original data into an Excel spreadsheet for storage. Data statistics are completed by software statistics and calculations. ${ }^{3}$ The measurement results are all expressed as mean \pm standard deviation. Exclude other sports training methods for single-factor statistical analysis.

\section{The high-intensity sports injury model}

The active contour model is the model with the smallest energy in mechanics. The deformation is essential that the active contour gradually approaches the damaged edge under external and internal energy combined. Assume that the snake point is in an equilibrium position. ${ }^{4}$ At this time, the corresponding energy is the smallest. Then the active contour will converge to the edge of the identified damaged part. Equation (1) is the contour energy expression

$$
E(C)=\left[\alpha E_{i n}(C)+\beta E_{e x}(C)\right] \operatorname{Gray}(i, j)
$$

$E(C)$ represents the energy of the damaged contour. $E_{\text {in }}(C)$ stands for internal energy. $E_{e x}(C)$ stands for external energy. $\alpha$ and $\beta$ represent weighted values. It can affect the internal energy value and the external energy value. ${ }^{5}$ We arrange the damaged image as a feature vector of length 64 according to the mode of column concatenation, then there is $X=$ $\left\{x_{1}, x_{2}, \cdots x_{m}\right\}$. Where $m$ represents the number of sports injury images. Calculating the overall mean vector of the image is expressed as follows

$$
\mu=\frac{1}{m} \sum_{i=1}^{m} x_{i} E(C)
$$

$u$ represents the overall mean vector of the image. We select the first $60 \%$ eigenvalues to preserve most of the information of the damaged image.

$$
u_{i}=A \frac{1}{\sqrt{\lambda_{i}}} X \cdot \tilde{\mathrm{o}}_{i} \cdot \mu
$$

$u_{i}$ represents the eigenvector value of the covariance matrix. $\lambda_{i}$ represents the non-zero eigenvalue of the matrix. $\tilde{\mathrm{o}}_{i}$ represents the vector corresponding to the non-zero eigenvalue. We project all training samples and the motion damage image samples to be recognized into the eigenspace $U$. Calculate the projection coefficient:

$$
y_{i}=U^{T} \cdot u_{i}
$$

\section{RESULTS}

\section{Analysis of changes in football's physical function of sports training students}

The impact of football training on the vital capacity of sports training students

This indicator is one of the important functional indicators reflecting the level of human growth and development. It can be seen from Table 1 that the vital capacity index of the experimental group students increased from $(3822 \pm 462.43) \mathrm{ml}$ to $(4371 \pm 627.56) \mathrm{ml}$, and the average value increased by $550 \mathrm{ml}$. The results showed a significant difference $(p<0.05)$. The vital capacity index of the students in the control group increased from $(3720 \pm 228.76) \mathrm{ml}$ to $(3730 \pm 204.40) \mathrm{ml}$. There is almost no difference ( $p>0.05$ ), which belongs to normal physiological growth. It can be seen that a larger amount of football training exercise will cause an increase in vital capacity and thus improve cardiopulmonary function. ${ }^{6}$

The influence of the basic heart rate of students majoring in physical training

Basal heart rate refers to the heart rate before waking up in the morning. Measuring basic heart rate can understand the functional status and evaluate the effect of exercise. It can be seen from Table 2 that the basal heart rate of the experimental group decreased from $(65.5 \pm 2.06)$ beats/min to $(62.9 \pm 3.02)$ beats/min. The results showed a significant difference $(p<0.05)$. The basal heart rate of the control group decreased from $(65.7 \pm 1.74)$ beats/min to $(65.2 \pm 1.93)$ beats/min. There is almost no difference ( $p>0.05)$.

\section{Analysis of changes in the physical fitness of sports training majors caused by football auxiliary training methods}

The influence of the auxiliary training method of 12-minute running on the endurance quality of sports training students

The 12-minute run is an important indicator reflecting the endurance quality of football players. In football, offensive and defensive conversion speeds are fast, and the game time is long. This requires athletes to have super strong physical endurance. It can be seen from Table 3 that the 12-minute running index of the experimental group students increased from $(2660 \pm 115)$ meters to $(3025 \pm 178)$ meters. ${ }^{7}$ The results showed a very significant difference $(p<0.01)$. The 12 -minute running index of the students in the control group increased from $(2600 \pm 127)$ meters to $(2620 \pm 126)$ meters. The results were not significantly different

Table 1. List of vital capacity indicators before and after football training.

\begin{tabular}{c|c|c|c|c|c}
\hline Group & $\mathbf{N}$ & $\begin{array}{c}\text { Before the } \\
\text { experiment }\end{array}$ & After the experiment & $\mathbf{t}$ & $\mathbf{p}$ \\
\hline Control group & 10 & $3720 \pm 228.76$ & $3730 \pm 204.40$ & 0.1 & $\mathrm{p}>0.05$ \\
\hline test group & 10 & $3822 \pm 462.43$ & $4371 \pm 627.56$ & 2.28 & $\mathrm{p}<0.05$ \\
\hline$T(P)$ & & $0.09(\mathrm{p}>0.05)$ & $3.07(\mathrm{p}<0.01)$ & & \\
\hline
\end{tabular}

Table 2. List of basic heart rate indicators before and after football training.

\begin{tabular}{c|c|c|c|c|c}
\hline Group & $\mathbf{N}$ & $\begin{array}{c}\text { Before the } \\
\text { experiment }\end{array}$ & After the experiment & $\mathbf{T}$ & $\mathbf{P}$ \\
\hline test group & 10 & $65.5 \pm 2.06$ & $62.9 \pm 3.02$ & 2.29 & $\mathrm{p}<0.05$ \\
\hline Control group & 10 & $65.7 \pm 1.74$ & $65.2 \pm 1.93$ & 0.61 & $\mathrm{p}>0.05$ \\
\hline$T(P)$ & & $0.23(\mathrm{p}>0.05)$ & $2.25(\mathrm{p}<0.05)$ & & \\
\hline
\end{tabular}

Table 3. List of 12-min running indicators before and after football-assisted training

\begin{tabular}{c|c|c|c|c|c}
\hline Group & $\mathbf{N}$ & $\begin{array}{c}\text { Before the } \\
\text { experiment }\end{array}$ & After the experiment & $\mathbf{T}$ & $\mathbf{P}$ \\
\hline test group & 10 & $2660 \pm 115$ & $3025 \pm 178$ & 5.45 & $\mathrm{p}<0.01$ \\
\hline Control group & 10 & $2600 \pm 127$ & $2620 \pm 126$ & 0.35 & $\mathrm{p}>0.05$ \\
\hline$T(P)$ & & $1.11(\mathrm{p}>0.05)$ & $5.87(\mathrm{p}<0.01)$ & & \\
\hline
\end{tabular}


( $p>0.05$ ). The 12-minute running level of the students in the experimental group was greatly improved after the experiment, which was significantly different from the control group after the experiment $(p<0.01)$. The 12-minute running auxiliary training is due to many exercises, the long-range running, and the longer time. This can well stimulate the students' endurance quality. Therefore, football-assisted training has a great effect on the improvement of students' endurance quality.

The influence of the auxiliary training method of the $25 \mathrm{~m}$ turnback run on the sensitivity of sports training students

The 25-meter turnback run is mainly to measure the coordination and agility of the body. It can be seen from Table 4 that the return run index of the experimental group decreased from $(9.55 \pm 0.42) \mathrm{s}$ to $(8.47 \pm 0.57) \mathrm{s}$. The results showed a very significant difference $(p<0.01)$. The return run index of the control group changed from $(9.98 \pm 0.58) \mathrm{s}$ to $(9.87 \pm 0.36) \mathrm{s}$, and the results showed no significant difference $(p>0.05)$. There is a very significant difference between the experimental and control groups in the index after the experiment $(p<0.01)$. This shows that football-assisted training can well improve the coordination and agility of students.

Football games are mainly based on running with the ball and running without the ball. During the fast break, athletes must have a great instantaneous burst speed, ability to change direction, and ability to react. ${ }^{8}$ Therefore, long-term football training can significantly improve students' instantaneous burst speed, physical coordination sensitivity, and reaction ability.

The influence of the auxiliary training method of standing flexion on the flexibility quality of sports training students

Standing forward flexion is a test item that reflects the flexibility of the human body. It can be seen from Table 5 that the three-dimensional forward bending index of the students in the experimental group increased from $(10.54 \pm 8.81) \mathrm{cm}$ to $(13.05 \pm 8.83) \mathrm{cm}$. The results were not significantly different $(p>0.05)$. But it can improve students' flexibility. ${ }^{9}$ The three-dimensional forward bending index of the control group increased from $(10.39 \pm 8.16) \mathrm{cm}$ to $(10.40 \pm 8.12) \mathrm{cm}$, and the results were not significantly different $(p>0.05)$. However, there is a significant difference between the experimental and control groups in the data after the experiment $(p<0.05)$. Because the practice of football-assisted training methods has a certain impact on students' flexibility, football training can play a certain role in promoting the development of students' flexibility.

Table 4. List of $25 \mathrm{~m}$ turnback running indexes before and after football-assisted training.

\begin{tabular}{c|c|c|c|c|c}
\hline Group & $\mathbf{N}$ & $\begin{array}{c}\text { Before the } \\
\text { experiment }\end{array}$ & After the experiment & $\mathbf{T}$ & $\mathbf{P}$ \\
\hline test group & 10 & $9.55 \pm 0.42$ & $8.47 \pm 0.57$ & 4.82 & $\mathrm{p}<0.01$ \\
\hline Control group & 10 & $9.98 \pm 0.58$ & $9.87 \pm 0.36$ & 0.51 & $\mathrm{p}>0.05$ \\
\hline$T(P)$ & & $1.89(\mathrm{p}>0.05)$ & $6.57(\mathrm{p}<0.01)$ & & \\
\hline
\end{tabular}

Table 5. List of three-dimensional forward bending indexes before and after football-assisted training.

\begin{tabular}{c|c|c|c|c|c}
\hline Group & $\mathbf{N}$ & $\begin{array}{c}\text { Before the } \\
\text { experiment }\end{array}$ & After the experiment & $\mathbf{T}$ & $\mathbf{P}$ \\
\hline test group & 10 & $10.54 \pm 8.81$ & $13.05 \pm 8.83$ & 1.64 & $\mathrm{p}>0.05$ \\
\hline Control group & 10 & $10.39 \pm 8.16$ & $10.40 \pm 8.12$ & 0.002 & $\mathrm{p}>0.05$ \\
\hline$T(\mathrm{P})$ & & $0.04(\mathrm{p}>0.05)$ & $2.13(\mathrm{p}<0.05)$ & & \\
\hline
\end{tabular}

The effect of the auxiliary training method of dribbling figure-of-eight running on the coordination quality of sports training students

The figure-of-eight running with the ball is a test in which the student takes the ball along the figure-eight route and bypasses two markers separated by 5 meters. It mainly reflects the student's coordination ability. ${ }^{10}$ It can be seen from Table 6 that football-assisted training can significantly improve the coordination quality of students. The index of the experimental group decreased from $(8.83 \pm 0.57) \mathrm{s}$ to $(7.36 \pm 0.41) \mathrm{s}$. The results are very significant $(p<0.01)$. The index of the control group decreased from $(9.04 \pm 0.16) \mathrm{s}$ to $(9.00 \pm 0.26) \mathrm{s}$. The results were not significantly different ( $p>0.05$ ). The experimental and control groups'data were also significantly different after the experiment $(p<0.01)$. This is related to the lack of football knowledge and professional training in the control group. This shows that specialized football training can improve the coordination ability of the students based on increasing the students' playing ability.

Table 6. List of figures of figure-eight running with the ball before and after football assisted training.

\begin{tabular}{c|c|c|c|c|c}
\hline Group & $\mathbf{N}$ & $\begin{array}{c}\text { Before the } \\
\text { experiment }\end{array}$ & After the experiment & $\mathbf{T}$ & $\mathbf{P}$ \\
\hline test group & 10 & $8.83 \pm 0.57$ & $7.36 \pm 0.41$ & 6.62 & $\mathrm{p}<0.01$ \\
\hline Control group & 10 & $9.04 \pm 0.16$ & $9.00 \pm 0.26$ & 0.41 & $\mathrm{p}>0.05$ \\
\hline$T(P)$ & & $1.12(\mathrm{p}>0.05)$ & $10.68(\mathrm{p}<0.01)$ & & \\
\hline
\end{tabular}

\section{DISCUSSION}

The comparison results between the experimental group's experimental data and the control group's experimental data are also very significant $(p<0.01)$. Because football training is high-intensity training, it requires long-term high-speed running and heavy passes and shots. After specialized auxiliary exercises can play an important role in improving students' explosive power and lower limb strength. Therefore, in football training, attention should be paid to the coordinated development of the upper and lower limbs. While developing the muscles of the waist, abdomen, and thighs, it also pays attention to upper limb strength exercises. Several sets of dumbbell exercises and push-up exercises can be added after training. Football is a high-intensity sport. The training process is more difficult. Very good willpower is required during training and competition. In the process of football training, attention should be paid to continuous training. Only long-term training can achieve significant results. Attention should be paid to the control of training volume during football training. The amount of training must be within a reasonable range. We cannot blindly increase training in pursuit of the effect of exercise and the improvement of technical level. Attention should be paid to nutritional supplements during football training. Football training is a kind of high-intensity training, so it must have good nutrition protection.

\section{CONCLUSION}

Football training can significantly improve the cardiopulmonary function of college students. Football training can significantly improve the physical fitness of college students in terms of endurance, explosiveness, flexibility, overall balance, and coordination sensitivity.

All authors declare no potential conflict of interest related to this article

AUTHORS' CONTRIBUTIONS: Each author made significant individual contributions to this manuscript. Shihao Huang: writing and data analysis; Shiting Wu: performing surgeries; Yahui Su: article review and intellectual concept of the article.

\section{REFERENCES}

1. Ekstrand J, Lundqvist D, Davison $M, D^{\prime}$ Hooghe $M$, Pensgaard AM. Communication quality between the medical team and the head coach/manager is associated with injury burden and player availability in elite football clubs. British Journal of Sports Medicine. 2019:53(5):304-8.

2. Choriyev DI. Planning And Organizing Training Of Football Players. The American Journal of Social 
Science and Education Innovations. 2021;3(7):9-14.

3. Dongsheng H, Hui L. A Probe into the Necessity and Effective Path of Football Activities in Kindergartens Journal of Frontiers in Sport Research. 2021;1(1):68-71.

4. Jones S, Almousa S, Gibb A, Allamby N, Mullen R, Andersen TE et al. Injury incidence, prevalence and severity in high-level male youth football: a systematic review. Sports medicine. 2019;49(12):1879-99.

5. Kalinowski P, Jerszyński D, Nowakowska M, Pietranis, D. Starting and running speed on the example of football clubs from Berlin. Quality in Sport. 2020;6(2):56-63.

6. Kraynik $Y$, Mulyk $V$, Perevoznik $V$, Koval $S$. The use of running and jumping exercises in special motor training of young forwards 13-14 years old. Slobozhanskyi herald of science and sport. 2020;8(1):41-4.

7. Wellman AD, Coad SC, Flynn PJ, Siam TK, McLellan CP. Perceived wellness associated with practice and competition in National Collegiate Athletic Association Division I football players. The Journal of Strength \& Conditioning Research. 2019;33(1):112-24.

8. Kashuba V, Andrieieva O, Yarmolinsky L, Karp I, Kyrychenko V, Nosova N et al. Measures to prevent functional muscular disorders in sports training of 7-9-year-old football players. Journal of Physical Education and Sport. 2019;20(2):366-71.

9. Ryan S, Kempton T, Impellizzeri FM, Coutts AJ. Training monitoring in professional Australian football: theoretical basis and recommendations for coaches and scientists, Science and Medicine in Football. 2020;4(1):52-8.

10. Brown C, Holland A, Delarosa J, Doude M, Reimann W, Rath T et al. Comprehension and selective visual attention in play-calling signage in NCAA division 1 football: A comprehensive literature review. International Journal of Kinesiology and Sports Science. 2020;8(3):1-13. 